\title{
Surgical treatment of postpartum haemorrhage: national survey of French residents of obstetrics and gynecology
}

Pierre-Emmanuel Bouet ${ }^{*}$, Hugo Madar ${ }^{2}$, Alizée Froeliger ${ }^{2}$, Hady El Hachem ${ }^{3}$, Elsa Schinkel ${ }^{4}$, Aurélien Mattuizi ${ }^{2}$ and Loïc Sentilhes ${ }^{2}$

\begin{abstract}
Background: Postpartum haemorrhage (PPH) is a major cause of maternal morbidity and one of the leading causes of maternal mortality worldwide. Many medical treatments and interventions are available nowadays, but surgical treatment is sometimes required when less invasive methods are unsuccessful. This study aimed to assess the theoretical and practical knowledge of French residents of Obstetrics and Gynecology concerning the surgical treatment of postpartum haemorrhage.

Study design: We performed a questionnaire study for senior residents of Obstetrics and Gynecology in France (fourth and fifth year of training). An anonymous survey was sent by email. Between December 2013 and April 2014, a total of 370 residents responded.

Result: The response rate was 47.6\% (176/370). Only 156 questionnaires were fully completed and included for analysis. In all, 74\% (115/156) of residents reported not mastering sufficiently or at all the technique for bilateral ligation of uterine arteries, 79\% (123/156) for uterine compression sutures, 95\% (148/156) for ligation of the internal iliac arteries, and 78\% $(122 / 156)$ for emergency peripartum hysterectomy. More than half of respondents $(55 \%, 86 / 156)$ stated that they had not mastered any of these techniques.

Conclusion: An alarmingly high number of French senior residents in Obstetrics and Gynecology report that they have not acquired the sufficient surgical skills during their training to be able to perform the surgeries required for the management of PPH.
\end{abstract}

Keywords: Survey, Postpartum haemorrhage, Surgery, Residents

\section{Background}

Postpartum haemorrhage (PPH) is defined as a loss of more than $500 \mathrm{~mL}$ of blood within the first $24 \mathrm{~h}$ following childbirth and is a major cause of maternal morbidity and the leading cause of maternal mortality [1]. A recent review conducted by the World Health Organisation (WHO) that included data from 115 countries estimated that $27 \%$ of maternal deaths worldwide are due to PPH [1]. However, most PPH-related deaths are preventable. Indeed, the French national expert committee recently estimated

\footnotetext{
* Correspondence: pebouet@hotmail.com

${ }^{1}$ Department of Obstetrics and Gynecology, Montreal University Hospital, Montreal, Canada

Full list of author information is available at the end of the article
}

that more than $80 \%$ of mortality cases due to $\mathrm{PPH}$ were avoidable [2], a rate reported in many other countries with different demographics $[3,4]$. Surgical management is indicated when medical and less invasive approaches fail to control the bleeding, and can be conservative (when it involves simple vascular ligation), or radical (when it involves a hysterectomy). A recent French population based study including more than 140,000 deliveries reported conservative surgical management of $\mathrm{PPH}$ in $1.3 \%$ of cases and a hysterectomy in $1.1 \%$ of cases [5]. The incidence of emergency hysterectomies for PPH in the general population in high resource countries is around 1 per 2000 to 3500 deliveries [5-7]. However, and even though surgical treatment of PPH is rarely needed, it

(c) The Author(s). 2019 Open Access This article is distributed under the terms of the Creative Commons Attribution 4.0 International License (http://creativecommons.org/licenses/by/4.0/), which permits unrestricted use, distribution, and reproduction in any medium, provided you give appropriate credit to the original author(s) and the source, provide a link to the Creative Commons license, and indicate if changes were made. The Creative Commons Public Domain Dedication waiver (http://creativecommons.org/publicdomain/zero/1.0/) applies to the data made available in this article, unless otherwise stated. 
may be the only life saving option in several clinical scenarios, especially after failure of more conservative approaches, such as medical treatment with uterotonic agents, intrauterine tamponade or packing, or uterine artery embolization. Surgical management is even sometimes the only option in certain clinical settings [2].

In France, the law states that all obstetricians/gynecologists should acquire the necessary surgical skills during their training, in order to be able to perform an emergency hysterectomy for PPH [8]. Any failure to adequately perform a surgery for PPH when needed may result in a medical malpractice lawsuit. Therefore, national Obstetrics and Gynecology training programs must ensure that residents are adequately exposed and trained for the surgical management of PPH [9].

However, with the continuous improvement in the medical management of $\mathrm{PPH}$, the number of cases requiring a surgical intervention is low. It is therefore reasonable to suspect that some residents may not be sufficiently trained for such a scenario. The main objective of our study was to assess the theoretical and practical knowledge of senior Obstetrics and Gynecology residents in France concerning the surgical management of PPH. Our secondary objective was to evaluate the surgical management algorithms these residents would implement in their future practice when facing severe cases of PPH (blood loss $>1500 \mathrm{ml}$ ) not responding to medical and conservative management.

\section{Methods}

We performed an anonymous questionnaire study, which was approved by the Committee of Ethics and Research in Obstetrics and Gynecology (CEROG-2013-08).

An online survey containing 51 questions was sent by email to 370 post-graduate year 4. (PGY4) and post-graduate year 5 (PGY5) residents of Obstetrics and Gynecology. In France, the national Obstetrics and Gynecology residency training program is a 5-year program, and all residents are registered at the "Association des Gynécologues-Obstétriciens en Formation", which provided the list of residents and their email addresses. We only included PGY 4 and PGY 5 residents (senior residents) since, according to French legislation they are the only residents allowed to cover maternity wards as senior obstetricians, whether in private or public hospitals [10].

The survey was first piloted in our own department. An email was sent to the 370 eligible residents in December 2013, followed by 2 reminders in February and in April 2014. We collected answers until June 2014, and we only included fully answered questionnaires in the study. A questionnaire was considered eligible only when all questions were answered.
We could not find any validated questionnaire on the subject in the literature, so we designed our survey taking into account all the co-authors' input. We included binary and open-ended questions, as well as questions with the "other" option in answers in order to elicit alternate responses we could have missed.

The final survey we sent (Additional file 1) had three sections. The first had 12 questions that covered demographic and institutional data and the second had 38 questions about the theoretical and practical knowledge of the residents concerning PPH. The third section contained 3 questions about the surgical management algorithm the participants would apply for severe $\mathrm{PPH}$ in a hemodynamically stable patient who wishes to preserve her fertility.

The surgical techniques stated in the survey were: uterine compression sutures (UCS) [11, 12], bilateral uterine artery ligation (UAL) [13], triple uterine artery ligation (TUAL) [14, 15], emergency peripartum hysterectomy $(\mathrm{PH})$ [16], bilateral internal iliac artery ligation (IIAL) and stepwise uterine devascularization (SUD) [17-19].

An email was sent to each participant containing: 1) a cover letter explaining the study, stating that participation was voluntary, unremunerated, and anonymous for all, and indicating the amount of time needed to fill the questionnaire; 2) an internet link that directed the participants to the website (www.limesurvey.com) where the survey was posted. The survey was completed online. Unique identifiers were assigned to each participant's computer, thus ensuring that they could complete the questionnaire only once. Data were collected via Web-link and email and downloaded to a spreadsheet.

The primary endpoint of our study was the level of knowledge of the residents for each of the surgical techniques included in the survey. This was achieved by self-assessment and the participants had to reply whether they considered their level of expertise as complete, sufficient, insufficient, or absent, for each of the procedures (questions number 18, 24, 30,36, 42 and 48).

Our secondary endpoint was the type of surgery the residents would use as a first, second and third line treatment for PPH (questions 49-51).

Statistical analysis was performed with SPSS 15.0 for Windows (SPSS Inc., Chicago, IL, USA). Descriptive statistics were used to detail demographic characteristics, the theoretical and practical knowledge, and the different management strategies employed by participants.

\section{Results}

The response rate was $47.6 \%$ (176/370). Twenty questionnaires were not fully completed and were excluded from the study. One hundred fifty-six questionnaires were thus included in the final analysis. 
The participants' demographic data are presented in Table 1 . The median age of participants was 29 years (range: 28-30). They were equally distributed between PGY4 (77) and PGY5 (79) The mean amount of time spent training in surgical departments was 2.4 semesters. The mean number of obstetrical calls was 5.3 per month, and $94 \%$ of participants reported having a supervising obstetrician present on site during the

Table 1 Characteristics of residents who responded to the survey

\begin{tabular}{|c|c|}
\hline & Total $n=156$ \\
\hline \multicolumn{2}{|l|}{ Sex } \\
\hline - Female & $125(80 ; 73-86)$ \\
\hline • Male & $31(20 ; 14-27)$ \\
\hline Age (years) ${ }^{a}$ & $29(28-30)$ \\
\hline Semester & $8.1+/-1.2$ \\
\hline - 7th & $59(38 ; 33-44)$ \\
\hline - 8th & $18(11.5 ; 8-15)$ \\
\hline - 9th & $61(39 ; 36-42)$ \\
\hline$\cdot 10$ th & $18(11.5 ; 8.5-15)$ \\
\hline Semesters of surgery residency & $2.4+/-1.3$ \\
\hline \multicolumn{2}{|l|}{$\begin{array}{l}\text { Has provided obstetric care alone, without } \\
\text { senior obstetrician onsite }\end{array}$} \\
\hline - Yes & $22(14 ; 9-21)$ \\
\hline • No & $80(51 ; 43-59)$ \\
\hline - Not applicable ${ }^{b}$ & $54(35 ; 27-43)$ \\
\hline Number of obstetrical calls/month & $5.3+/-1.2$ \\
\hline $\begin{array}{l}\text { Number of obstetrical calls since the beginning } \\
\text { of residency }\end{array}$ & $196.3+/-84$ \\
\hline \multicolumn{2}{|l|}{$\begin{array}{l}\text { Considers severe PPH requiring surgical treatment } \\
\text { a situation that is: }\end{array}$} \\
\hline - Extremely stressful & $48(31 ; 24-39)$ \\
\hline - Stressful & $107(68.5 ; 61-76)$ \\
\hline - A little stressful & $1(0.5 ; 0-3.5)$ \\
\hline - Absolutely not stressful & 0 \\
\hline \multicolumn{2}{|l|}{$\begin{array}{l}\text { A senior obstetrician is always onsite when } \\
\text { respondent is on-call. }\end{array}$} \\
\hline - Yes & $147(94 ; 89-97)$ \\
\hline • No & $9(6 ; 3-11)$ \\
\hline \multicolumn{2}{|c|}{$\begin{array}{l}\text { Considers that he/she knows the department's protocol } \\
\text { for medical management of postpartum haemorrhage: }\end{array}$} \\
\hline - Completely & $81(52 ; 44-60)$ \\
\hline - Sufficiently & $68(43.5 ; 36-52)$ \\
\hline - Insufficiently & $7(4.5 ; 2-6)$ \\
\hline - Not at all & 0 \\
\hline
\end{tabular}

calls. Only $14 \%(22 / 156)$ had already covered senior obstetrical calls.

\section{$68.6 \%$ of residents $(107 / 156)$ found surgical treatment of PPH to be "stressful" and 30.8\% (48/ 156) found it "extremely stressful", whereas only one participant considered it not stressful}

The primary learning tools reported by residents were textbooks $(88 \%)$, lectures $(53 \%)$, the internet $(41 \%)$, specialized medical journals (31\%), and multimedia tools (28\%).

There was an important discrepancy between the theoretical and the practical knowledge for most of the techniques. Indeed, for UCS, 99\% of respondents (146/ 156) were satisfied with their theoretical understanding of the technique, but $74 \%(115 / 156)$ reported not mastering it sufficiently or at all. The same was noted for: UAL: $96 \%$ (150/156) and 79\% (123/156); TUAL 83\% $(132 / 156)$ and $85 \%(132 / 156) ;$ IIAL $94 \%(146 / 156)$ and 95\% (148/156); and PH 96\% (150/156) and 78\% (122/ 156). The only surgical method that was not well known to residents, both theoretically and practically, was SUD: 15\% (23/156) and 98\% (153/156). Finally, 55\% (86/156) reported not mastering any of the techniques.

$31 \%$ of participants $(48 / 156)$ had already performed UCS with an attending senior colleague, compared to $26 \%(40 / 156)$ for UAL, $19 \%(29 / 156)$ for TUAL, $1 \%(2 / 156)$ for SUD, $12 \%(19 / 156)$ for IIAL and $13 \%$ $(20 / 156)$ for $\mathrm{PH}$ (Table 2). On the other hand, $26 \%$ (40/156) had never seen nor assisted a UCS, 28\% $(43 / 156)$ a UAL, $46 \%(72 / 156)$ a TUAL, $99 \%(155 /$ $156)$ a SUD, $44 \%(69 / 156)$ an IIAL and $28 \%(44 / 156)$ a PH. Finally, $7 \%(11 / 156)$ had never seen nor assisted any of the techniques mentioned in a case of severe PPH (Table 2).

When asked about the surgical management of a severe $\mathrm{PPH}$ in a young and hemodynamically stable woman who wishes to preserve her fertility, 85 participants $(54.5 \%)$ responded that their first line treatment would be a distal ligation technique (UAL, TUAL or SUD), whereas 50 participants (32\%) chose UCS, 21(13.5\%) chose IIAL, and none chose PH. The second line treatment was, in decreasing order, IIAL $(42 \%, 66 / 156)$, followed by distal ligation technique $(36 \%, 56 / 156)$, UCS $(12 \%, 18 / 156)$ and $\mathrm{PH}$ $(10 \%, 16 / 156)$. Finally, the third line treatment was, in decreasing order, PH $(49 \%, 77 / 156)$, IIAL $(26 \%$, 40/156), UCS (11\%, 17/156), and distal ligation (UAL, TUAL or SUD) $(5 \%, 8 / 156)$. All results are summarized in Table 3.

The orders of surgeries most commonly reported by residents were: (1) distal ligation (TUAL or UAL), followed by IIAL, and PH in $29 \%$ of cases (45/156); and (2): UCS followed by distal ligation and $\mathrm{PH}$ in $20 \%$ of cases $(31 / 156)$. 
Table 2 Clinical experience reported by responding residents

\begin{tabular}{lllll}
\hline & Performed alone ${ }^{a}$ & $\begin{array}{l}\text { Performed with the help of a } \\
\text { senior obstetrician/gynecologist }\end{array}$ & Seen it performed ${ }^{{ }^{a}}$ & Never seen it performed $^{{ }^{a}}$ \\
\hline Uterine compression sutures & $3(2 ; 0.5-5.5)$ & $48(31 ; 24-39)$ & $75(48 ; 40-56)$ & $40(26 ; 19-33)$ \\
Bilateral ligation of the uterine arteries & $1(0.5 ; 0-3.5)$ & $40(26 ; 19-33)$ & $76(51 ; 43-59)$ & $43(28 ; 21-35)$ \\
Tsirulnikov's triple ligation & 0 & $29(19 ; 13-26)$ & $59(38 ; 30-46)$ & $72(46 ; 38-52)$ \\
Stepwise uterine devascularisation & 0 & $2(1 ; 0-5)$ & $1(0.5 ; 0-3.5)$ & $155(99 ; 96.5-100)$ \\
Bilateral ligation of the internal iliac arteries & $1(0.5 ; 0-3.5)$ & $19(12 ; 7.5-18)$ & $69(44 ; 36-52)$ & $69(44 ; 36-52)$ \\
Emergency hysterectomy & $1(0.5 ; 0-3.5)$ & $20(13 ; 8-19)$ & $93(60 ; 51.5-67)$ & $44(28 ; 21-36)$
\end{tabular}

The data are reported in (\%; 95\% confidence intervals)

aparticipating obstetricians reported the number of times they were confronted with each situation for each of the mentioned techniques

\section{Discussion}

Our survey shows that most senior Obstetrics and Gynecology residents in France have good theoretical knowledge of the different surgical techniques used in the management of severe PPH. However, an alarmingly high number of these residents -more than half- consider that they have not acquired the sufficient surgical skills during their training to be able to perform these techniques on their own. Moreover, a large proportion reported not being able to perform simple procedures that are considered standard in today's training programs, such as UAL (79\%), TUAL (85\%) and UCS (74\%).

Several hypotheses can be forwarded to explain the low level of mastery of these surgical methods by senior residents. First of all, the advent of uterine artery embolization (UAE) has significantly reduced the need for these surgeries in the past decade, since it is performed first according to many management algorithms $[5,16,20]$. This may explain, in part, why 25 to $30 \%$ of senior Obstetrics and Gynecology residents have never assisted or participated in a UAL, UCS or a PH. The second possibility is that, with the constantly increasing use of the laparoscopic approach in gynaecological surgery over the past 20 years [21], the number of total

Table 3 Techniques that participants would use as first, second, and third line treatment for surgical management of severe PPH in a haemodynamically stable patient

\begin{tabular}{|c|c|c|c|}
\hline & First line & $\begin{array}{l}\text { Third } \\
\text { line }\end{array}$ & $\begin{array}{l}\text { Third } \\
\text { line }\end{array}$ \\
\hline Uterine compression techniques & $\begin{array}{l}50(32 ; 25- \\
40)\end{array}$ & $\begin{array}{l}18(12 ; 7- \\
18)\end{array}$ & $\begin{array}{l}17(11 ; 6- \\
17)\end{array}$ \\
\hline $\begin{array}{l}\text { Distal ligation (of the uterine arteries } \\
\text { or Tsirulnikov's triple ligation or } \\
\text { stepwise uterine devascularisation) }\end{array}$ & $\begin{array}{l}85(54.5 \\
46-62)\end{array}$ & $\begin{array}{l}56(36 ; \\
28-44)\end{array}$ & $\begin{array}{l}8(5 ; 2- \\
10)\end{array}$ \\
\hline $\begin{array}{l}\text { Bilateral ligation of the internal } \\
\text { iliac arteries }\end{array}$ & $\begin{array}{l}21(13.5 \\
8-20)\end{array}$ & $\begin{array}{l}66(42 ; \\
34-50)\end{array}$ & $\begin{array}{l}40(26 ; \\
19-33)\end{array}$ \\
\hline Emergency hysterectomy & 0 & $\begin{array}{l}16(10 ; 6- \\
16)\end{array}$ & $\begin{array}{l}77(49 ; \\
41-57)\end{array}$ \\
\hline $\begin{array}{l}\text { None, a hysterectomy was } \\
\text { 12already done }\end{array}$ & & 0 & $\begin{array}{l}16(10 ; 6- \\
16)\end{array}$ \\
\hline
\end{tabular}

The data are reported in (\%; $95 \%$ confidence intervals) abdominal hysterectomies done by laparotomy has decreased. Therefore, many residents are not well trained to perform total abdominal hysterectomies in other non-urgent settings, and thus find it hard to perform it in an urgent PPH setting. Indeed, $78 \%$ of respondents reported not having the required skills to perform a $\mathrm{PH}$. The third argument is that, in recent years, there has been a trend of overspecialization in the field of Obstetrics and Gynecology, and it is being felt even from the early days of residency training. From our point of view, this might limit the exposure of residents to total abdominal hysterectomies. However, one could argue that overspecialization, as well as the significant improvement in minimally invasive techniques, have considerably improved the quality of care available nowadays. Therefore, the care system has to find new ways and develop new learning tools in order to adjust and keep evolving at the same place. A fourth explanation is the decreasing surgical exposure time of residents since the application of the 2001 French law prohibiting all residents from working on the day following a night call [22]. Finally, since most $\mathrm{PPH}$ cases requiring surgical intervention are urgent and life threatening, it is not always possible for the supervising senior obstetrician to take the time to train, guide or assist a junior resident who can be overwhelmed by the situation.

All the aforementioned factors are directly affecting the quality of the current Obstetrics and Gynecology residency training program in France. The issue could be further compounded in the near future if some proposed reforms are applied. These reforms aim at shortening the length of the training program (4 years instead of 5) while guiding residents towards subspecialisation in the field early on during training [23]. Academic professors and physicians in charge of training should be aware of the current difficulties and could develop alternate teaching strategies, such as video teaching sessions [24], specialized books and publications [25, 26], instructional charts, diagrams and iconography [27, 28], and masterclasses and workshops with simulation and hands-on training [29-33]. Such auxiliary educational 
methods could help alleviate the lack of surgical exposure and play an important part in training residents to deal with cases of severe PPH.

Most residents in our survey preferred the distal ligation (54.4\%) and the uterine compression technique (32\%) as a first line treatment, rather than IIAL (13.5\%). This is in line with several reports in the literature stating that uterine artery ligation and uterine compression are more efficient than IIAL for the control of PPH [16, 27]. Moreover, according to different reports, the mean success rate of IIAL seems to be $69 \%$ (39-100\%), compared to $93 \%$ for uterine artery ligation and $83 \%$ for uterine compression $[34,35]$. However, due to the lack of direct comparative studies between the different techniques, most international societies refrain from recommending one procedure over the other in their guidelines for the management of $\mathrm{PPH}$ $[2,28,36-38]$. Taking into account that more than half of participants (55\%) consider they do not master any of the surgical techniques for management of $\mathrm{PPH}$, and that IIAL is associated with a longer learning curve and a higher morbidity [31, 35], we believe it would be more useful to concentrate the efforts on teaching residents the other techniques, such as UAL, UCS and $\mathrm{PH}$, even if the debate on efficacy remains open.

The main limitation of our study is that it is based on a self-assessment questionnaire. Moreover, the response rate was low, but it is comparable to rates reported in similar studies in the literature [39]. However, and to the best of our knowledge, this is the first survey study in the literature assessing the theoretical and practical knowledge of Obstetrics and Gynecology residents concerning the surgical management of PPH. We believe it can be helpful for evaluating and improving training programs in Obstetrics and Gynecology.

\section{Conclusions}

In conclusion, our survey study showed that $55 \%$ of French senior residents of Obstetrics and Gynecology consider that they do not master the surgical techniques required for the management of $\mathrm{PPH}$, and that $78 \%$ do not have the necessary skills to perform an emergency peripartum hysterectomy. We believe these numbers should serve as an alert that major work is needed in order to improve the training program regarding the surgical management of $\mathrm{PPH}$ in France. The various conservative surgical methods have a 70$90 \%$ efficiency rate $[19,35]$ and allow for preservation of future fertility for young patients with $\mathrm{PPH}$, whereas peripartum hysterectomy remains the ultimate life-saving treatment in case of failure of the medical or conservative surgical methods. PPH is the leading cause of maternal mortality, and it is essential that future obstetricians be well trained to surgically manage it.

\section{Additional file}

Additional file 1: Questionnaire about the surgical management of severe postpartum haemorrhage. (DOCX $22 \mathrm{~kb}$ )

\section{Abbreviations}

IIAL: Bilateral internal iliac artery ligation; $\mathrm{PH}$ : Emergency peripartum hysterectomy; PPH: Postpartum haemorrhage; SUD: Stepwise uterine devascularisation; TUAL: Triple uterine artery ligation; UAL: Bilateral uterine artery ligation; UCS: Uterine compression sutures

\section{Acknowledgements}

None.

Funding

None.

Availability of data and materials

The dataset used during the current study are available from the corresponding author on reasonable request, and after approval of the research group.

\section{Authors' contributions}

PEB analysed the data and wrote the first draft of the manuscript. LS conceived and designed the study, analysed the data and provided critical revision of the manuscript for important intellectual content. HM, AF, HEH, ES and $\mathrm{AM}$ made a substantial contribution to the acquisition of data. HM, AF, $\mathrm{HEH}, \mathrm{ES}$ and AM provided critical revision of the manuscript for important intellectual content. All authors approved the final version.

\section{Ethics approval and consent to participate}

Our study was approved by the french Committee of Ethics and Research in Obstetrics and Gynecology (CEROG-2013-08). The need for consent was waived by the french Committee of Ethics and Research in Obstetrics and Gynecology because our study consisted of an online survey sent by email to 370 residents of Obstetrics and Gynecology and did not concern patients.

Consent for publication

Not applicable.

\section{Competing interests}

Loïc Sentilhes was a board member, lecturer, and consultant for Ferring; the other authors declared no conflict of interest.

\section{Publisher's Note}

Springer Nature remains neutral with regard to jurisdictional claims in published maps and institutional affiliations.

\section{Author details}

${ }^{1}$ Department of Obstetrics and Gynecology, Montreal University Hospital, Montreal, Canada. ${ }^{2}$ Department of Obstetrics and Gynecology, Bordeaux University Hospital, Bordeaux, France. ${ }^{3}$ Department of Obstetrics and Gynecology, Clemenceau Medical Center, Beirut, Lebanon. ${ }^{4}$ Clinical Research Center, Angers University Hospital, Angers, France.

Received: 17 October 2017 Revised: 26 February 2019

Accepted: 5 March 2019 Published online: 13 March 2019

References

1. Deneux-Tharaux C, Bonnet MP, Tort J. Epidemiology of post-partum haemorrhage. J Gynecol Obstet Biol Reprod. 2014;43:936-50.

2. Sentilhes L, Vayssière C, Deneux-Tharaux C, Guy Aya A, Bayoumeu F, Bonnet MP, et al. Postpartum hemorrhage: guidelines for clinical practice from the French College of Gynaecologists and Obstetricians (CNGOF). Eur J Obstet Gynecol Reprod Biol. 2016;198:12-21.

3. Berg CJ, Harper MA, Atkinson SM, Bell EA, Brown HL, Hage ML, et al. Preventability of pregnancy-related deaths: results of a state-wide review. Obstet Gynecol. 2005;106:1228-34. 
4. Farquhar C, Sadler L, Masson V, Bohm G. Haslam. Beyond the numbers: classifying contributory factors and potentially avoidable maternal deaths in new-Zealand 2006-2009. Am J Obstet Gynecol. 2011;331(e331-e338):205.

5. Kayem G, Dupont C, Bouvier-Colle MH, Rudigoz RC, Deneux-Tharaux C. Invasive therapies for primary postpartum haemorrhage: a population-based study in France. BJOG. 2016;123:598-605.

6. Knight M. Peripartum hysterectomy in the UK: management and outcomes of the associated haemorrhage. BJOG. 2007;114:1380-7.

7. Stivanello E, Knight M, Dallolio L, Frammartino B, Rizzo N, Fantini MP. Peripartum hysterectomy and cesarean delivery: a population-based study. Acta Obstet Gynecol Scand. 2010;89:321-7.

8. Fédération nationale des collèges des spécialités chirurgicales. GynécologieObstétrique/Orthopédie-Traumatologie/Urologie. Référentiels et compétence en chirurgie. Décembre 2007:9-22. Avalaible at http://www. academie-chirurgie.fr/recomm/referentiel_metier_chir_gyn0607.pdf. Accessed 8 Mar 2019.

9. Collège Nationale des Gynécologues Obstétriciens Français - Association des Gynécologues et Obstétriciens en Formation. Livret de l'interne en gynécologie-obstétrique 2008. Module 8:41-47. Available at https:// docplayer.fr/20688274-c-n-g-o-f-a-g-o-f-livret-de-l-interne-en-gynecologieobstetrique.html. Accessed 8 Mar 2019.

10. Décret N. 2014-1075 du 22 septembre 2014 relatif à l'exercice de la profession de médecin par les internes en médecine mis en disponibilité à la demande d'inscription au tableau de l'ordre avant l'obtention du diplôme d'Etat de docteur en médecine et à la mise à jour de l'annexe 411 mentionnée à l'article D.4131-1 du code de la santé publique. Journal Officiel de la République Française. 2014;222:15594.

11. B-Lynch C, Coker A, Lawal AH, Abu J, Cowen MJ. The B-Lynch surgical technique for the control of massive postpartum haemorrhage: an alternative to hysterectomy? Five cases reported. BJOG. 1997;104:372-5.

12. Sentilhes L, Gromez A, Razzouk K, Resch B, Verspyck E, Marpeau L. B-Lynch suture for massive persistent postpartum hemorrhage following stepwise uterine devascularization. Acta Obstet Gynecol Scand. 2008;16:1-7.

13. O'Leary JA. Uterine artery ligation in the control of postcesarean hemorrhage. J Reprod Med. 1995;40:189-93.

14. Tsirulnikov MS. La ligature des vaisseaux utérins au cours des hémorragies obstétricales. J Gynecol Obstet Biol Reprod. 1979;8:751-3.

15. Sentilhes $L$, Trichot $C$, Resch $B$, et al. Fertility and pregnancy outcomes following uterine devascularization for postpartum haemorrhage. Hum Reprod. 2008;23:1087-92.

16. Sentilhes L, Kayem G, Descamps P. Factors associated with peripartum hysterectomy. Obstet Gynecol. 2009;114:927.

17. Sentilhes $L$, Descamps $P$. Which surgery should be the first-line uterinesparing procedure to control severe postpartum hemorrhage? Fertil Steril. 2011;95:e71.

18. AbdRabbo S. Stepwise uterine devascularization: a novel technique for management of uncontrollable postpartum hemorrhage with preservation of the uterus. Am J Obstet Gynecol. 1994;171:694-700.

19. Sentilhes L, Gromez A, Trichot C, Ricbourg-Schneider A, Descamps P, Marpeau L. Fertility after B-Lynch suture and stepwise uterine devascularization. Fertil Steril. 2009;91:934.e5-9.

20. Sentilhes L, Gromez A, Clavier E, Resch B, Verspyck E, Marpeau L. Fertility and pregnancy following pelvic arterial embolization for postpartum haemorrhage. BJOG. 2010;117:84-93.

21. Perron-Burdick M, Calhoun A, Idowu D, Pressman A, Zaritsky E. Minilaparotomy vs. laparoscopic hysterectomy: comparison of length of hospital stay. J Minim Invasive Gynecol. 2014;21:619-23.

22. Arrêté du 14 septembre 2001 relatif à l'organisation et à l'indemnisation des services de garde et à la mise en place du repos de sécurité dans les établissements publics de santé autres que les hôpitaux locaux. Journal Officiel de la République Française. 2001;217:14853.

23. Couraud D, Pruvot FR. Propositions pour une restructuration du troisième cycle des études médicales. http://www.cngof.fr/accueil-cngof/ commissions-du-cngof/apercu?path=Commissions\%2BCNGOF\%2B2017 Conference\%2Bdes\%2Benseignants.pdf\&i=12854. Accessed 8 Mar 2019

24. Resch B, Sergent F, Blanc $S$, Baron $M$, Roman $H$, Sentilhes $L$ et al. Prise en charge chirurgicale des hémorragies de la délivrance. 30èmes journées nationales du Collège nationale de gynécologie-obstétrique. Techniques chirurgicales et obstétricales en vidéo, DVD 2006. https://www.decitre.fr/ media/pdf/feuilletage/sommaire/9/7/8/2/2/9/4/7/9782294716492_SOM.pdf. Accessed 8 Mar 2019
25. Arulkumaran S, Karoshi M, Keith LG, Lalonde AB, B-Lynch C. A comprehensive textbook of postpartum hemorrhage. An essential clinical reference for effective management. 2nd ed. London: Sapiens Publishing Ltd; 2012.

26. Deruelle P, Kayem G, Sentilhes L. Chirurgie en obstétrique. Chirurgie de la femme enceinte et de l'accouchement. Paris: Elsevier-Masson; 2015.

27. Sentilhes L, Resch B, Gromez A, Clavier E, Ricbourg-Schneider A, Trichot C et al. Traitements chirurgicaux et alternatives non médicales des hémorragies de la délivrance. EMC Techniques chirurgicales. 2010. p1-20 [41-905].

28. Haumonté JB, Sentilhes L, Macé P, Cravello L, Boubli L, d'Ercole C. Surgical treatment of postpartum hemorrhage. J Gynecol Obstet Biol Reprod. 2014; 43:1083-103.

29. Deering SH, Chinn M, Hodor J, Benedetti T, Mandel LS, Goff B. Use of postpartum hemorrhage simulator for instruction and evaluation of residents. J Grad Med Educ. 2009;1:260-3.

30. Bouet PE, Brun S, Madar H, Schinkel E, Merlot B, Sentilhes L. Surgical management of postpartum haemorrhage: national survey of French obstetricians. Sci Rep. 2016;6:30342

31. Sentilhes L, Merlot B, Madar H, Brun S, Sztark F, Deneux-Tharaux C. Postpartum haemorrhage: prevention and treatment. Expert Rev Hematol. 2016;9:1043-61

32. Sentilhes $L$, Goffinet $F$, Vayssière $C$. Deneux-Tharaux. Comparison of postpartum haemorrhage guidelines: discrepancies underline our ignorance. BJOG. 2017:124:718-22.

33. Royal College of Obstetricians and Gynaecologists. Master Class in management of PPH 2019. https://www.rcog.org.uk/globalassets/ documents/courses-exams-and-events/postgraduate-and-scientific-events/ 2019/programmes/master-class-in-pph-programme-2019.pdf

34. Doumouchtsis SK, Papageorghiou AT, Arulkumaran S. Systematic review of conservative management of postpartum hemorrhage: what to do when medical treatment fails. Obstet Gynecol Surv. 2007;62:540-7.

35. Sentilhes $L$, Gromez A, Descamps P, Marpeau L. Why stepwise uterine devascularization should be the first-line conservative surgical treatment to control severe postpartum hemorrhage? Acta Obstet Gynecol Scand. 2009; 88:490-2.

36. American College of Obstetricians and Gynecologists. Clinical management guidelines for obstetricians-gynecologists: postpartum hemorrhage. ACOG practice bulletin no.76. Obstet Gynecol. 2006;108:1039-47.

37. Royal College of Obstetrician and Gynaecologists. Postpartum hemorrhage: prevention and management. April 2011. Available at: https:/www.rcog.org. uk/en/guidelines-research-services/guidelines/gtg52/. Accessed 8 Mar 2019.

38. Joshi VM, Otiv SR, Majumder R, Nikam YA, Shrivastava M. Internal iliac artery ligation for arresting postpartum hemorrhage. BJOG. 2007;114:356-61.

39. Plant MA, Fish JS. Resident use of internet,e-mail, and personal electronics in the care of surgical patients. Teach Learn Med. 2015;27:215-23.

Ready to submit your research? Choose BMC and benefit from:

- fast, convenient online submission

- thorough peer review by experienced researchers in your field

- rapid publication on acceptance

- support for research data, including large and complex data types

- gold Open Access which fosters wider collaboration and increased citations

- maximum visibility for your research: over $100 \mathrm{M}$ website views per year

At $\mathrm{BMC}$, research is always in progress.

Learn more biomedcentral.com/submission 